\title{
KENDALA-KENDALA GURU DALAM PEMBELAJARAN SEJARAH KONTROVERSIAL DI SMA NEGERI KOTA SEMARANG
}

\author{
Tsabit Azinar Ahmad, Ibnu Sodiq, Andy Suryadi \\ Jurusan Sejarah Universitas Negeri Semarang \\ azinarahmad@mail.unnes.ac.id
}

\begin{abstract}
This research identifies teacher constraints in controversial history learning in Semarang's senior high school and analyzes teachers' efforts in controversial history learning. Qualitative approach was used in this research to observe senior high school in Semarang Municipality. This research used interactive model of analysis. This research results three main factors that support controversial history learning i.e. school aspects, teachers' independency, and students' ability. There were several constraints in controversial history learning i.e. constraints in learning design, learning practices, and supporting factors. Commonly, it caused by two factors: (1) internal factors, there were historiographical change in Indonesia; (2) external factor, there were learning practices aspects. Teachers' effort to reduce learning constraints divided became two, learning design and learning practice's effort.
\end{abstract}

Keywords: learning history, controversial history, learning constraints.

\begin{abstract}
ABSTRAK
Tujuan penelitian ini adalah mengidentifikasi kendala-kendala yang ditemui guru dalam menganalisis upaya-upaya yang dilakukan guru dalam pembelajaran sejarah kontroversial. Penelitian ini menggunakan metode kualitatif dengan mengambil penelitian di SMA-SMA Negeri di Kota Semarang. Analisis yang dilakukan menggunakan model analisis model interaktif. Hasil penelitian memperlihatkan bahwa ada tiga hal yang mendorong pelaksanaan pembelajaran sejarah kontroversial, yakni sekolah, kemandirian guru dan kemampuan peserta didik. Kendala-kendala yang ditemui, yakni kendala pada saat perencanaan, kendala pada saat pelaksanaan pembelajaran dan pendukung. Kendala tersebut dapat disebabkan oleh dua faktor, yakni (1) faktor intern berupa perubahan corak historiografi Indonesa dan (2) faktor ekstern, yakni dari lam praksis pembelajaran. Upaya untuk mengatasi kendala-kendala terbagi menjadi dua, yakni upaya pada aspek perencanaan dan upaya pada aspek pelaksanaan pembelajaran.
\end{abstract}

Kata kunci: pembelajaran sejarah, sejarah kontroversial, kendala-kendala pembelajaran

\section{PENDAHULUAN}

Semenjak bergulirnya reformasi, perubahan-perubahan terjadi dalam berbagai aspek kehidupan bangsa Indonesia. Salah satu perubahan yang paling menonjol adalah dengan terwujudnya satu keadaan yang memungkinkan masyarakat untuk mengemukakan pendapatnya secara bebas. Adanya kebebasan dalam mengungkapkan pendapat menjadi satu indikator dari pencapaian iklim yang demokratis dalam sebuah sistem pemerintahan. Reformasi telah mengubah mind set atau pola pikir sebagian besar masyarakat menjadi lebih terbuka dan memiliki keluasan pandangan tentang kondisi diri dan lingkungannya.

Perubahan pola pikir masyarakat yang ditunjang dengan adanya serangkaian perubahan kebijakan 
pemerintah posreformasi telah membawa seperangkat perubahan dalam bidang sejarah. Adanya reformasi telah membawa satu tahapan baru dalam historiografi Indonesia yang oleh Kuntowijoyo disebut dengan gelombang ketiga historiografi Indonesia (Adam, 2007:89). Gelombang pertama disebut sebagai dekolonisasi sejarah dan gelombang kedua ditandai dengan adanya pemanfaatan ilmu sosial dalam sejarah. Sementara itu gelombang ketiga dalam historiografi Indonesia ditandai dengan adanya upaya pelurusan terhadap halhal kontroversial dalam sejarah yang ditulis semasa Orde Baru.

Perspektif penulisan sejarah posreformasi telah mengalami suatu dinamika. Hal ini dapat dilihat dengan bermunculannya trend yang disebut sebagai "sejarah korban" (Adam, 2007:9). Sejarah korban merupakan sejarah yang ditulis berdasarkan perspektif dari pihak yang merasa dirugikan atau yang menjadi korban dalam suatu peristiwa sejarah dan penulisannya di kemudian hari. Adam (2007:9-14) memberikan penjelasan tentang ciri dari gelombang ketiga sejarah Indonesia yakni (1) penulisan sejarah "terlarang", (2) penerbitan sejarah akademis yang kritis, serta (3) penerbitan biografi tokoh terbuang. Dengan adanya hal-hal tersebut, sejak reformasi telah terjadi pergeseran paradigma dan dinamisasi penulisan sejarah, dari sejarah yang semula bersifat tunggal versi resmi pemerintah menjadi sejarah yang lebih beragam dengan adanya beberapa versi yang muncul dalam masyarakat.

Adanya perbedaan pandangan dengan bermunculannya beragam versi ini telah menjadikan peristiwa sejarah menjadi bersifat kontroversial. Sejarah yang bersifat kontroversial dapat diartikan sebagai sejarah yang dalam penulisannya terdapat beberapa pendapat yang berbeda, yang pada akhir- nya memunculkan beberapa versi. Dikatakan kontroversial karena antara pendapat satu dengan pedapat lainnya masing-masing memiliki landasan yang menurut penulisnya adalah kuat (Ahmad, 2008:10).

Sifat kontroversial hampir selalu ada dalam sejarah. Hal ini dikarenakan sejarah senantiasa berproses dan bukan sebagai suatu hal yang sudah selesai, sehingga ada kecenderungan munculnya fakta-fakta dan interpretasiinterpretasi baru terhadap suatu peristiwa sejarah. Dengan demikian terdapat beberapa pendapat yang berbeda tetang suatu peristiwa sejarah, yang pada akhirnya memunculkan beberapa versi. Sejarah kontroversial senantiasa muncul akibat perbedaan pandangan tentang suatu peristiwa di kalangan sejarawan atau masyarakat yang dilandasi perbedaan perolehan sumber sampai dengan masalah interpretasi yang berbeda. Sehubungan dengan sifat kontroversi dalam sejarah, Kochhar (2008:450) menyatakan bahwa "hampir setiap hal yang kita ajarkan merupakan sesuatu yang kontroversial atau memiliki unsur kontroversi di dalamnya. Semakin banyak kita menginterpretasikan masa sekarang dengan bantuan masa lalu, semakin besar pula kemungkinan kita menemukan isu-isu kontroversial".

Sejarah kontroversial dapat diartikan sebagai sejarah yang dalam penulisannya terdapat beberapa pendapat yang berbeda, yang pada akhirnya memunculkan beberapa versi bahkan pertentangan antarversi. Pada sejarah kontroversial, antara pendapat satu dengan pendapat lain masingmasing memiliki landasan yang menurut penulisnya adalah kuat. Sebuah isu dapat menjadi kontroversial karena memberi dampak politik, sosial, maupun personal serta membangkitkan perasaan karena berkaitan dengan hal yang mempertanyakan kepercayaan 
dan nilai yang dianut (Global Citizenship Guides, 2006: 2). Permasalahan tersebut dapat menjadi lebih rumit apabila sulit untuk dijelaskan dan disebabkan adanya perbedaan yang kuat dalam cara pandang terhadap perbedaan karena masalah pengalaman, minat, dan nilainilai tertentu.

Cavet (2007: 2) mengutip The report Teaching controversial issues: A European perspective from the Children's Identity $\mathcal{E}$ Citizenship in Europe programme menyatakan bahwa "a controversial issue is one in which: there are competing values and interests; there is political sensitivity; emotions become strongly aroused; the subject/area is complex; the subject/area is of topical interest". (masalah kontroversial adalah satu di mana: ada bersaing nilainilai dan kepentingan, ada sensitivitas politik; emosi menjadi sangat terangsang; subjek/area adalah kompleks; subjek/kawasan adalah kepentingan topikal).

Kemunculan sejarah kontroversial tersebut telah membawa perubahan dalam pendidikan sejarah. Perubahan tersebut paling tidak nampak pada aspek materi ajar dari sejarah. Adanya perubahan dalam dunia pendidikan sejarah berkaitan dengan munculnya sejarah kontroversial, pada dasarnya justru membawa pendidikan sejarah ke arah pendidikan ideal, yaitu satu tahapan yang mampu membawa peserta didik menuju ke arah kedewasaan. Hal ini dikarenakan pembelajaran sejarah kontroversial secara proporsional akan memberikan kemampuan peserta didik untuk berpikir secara kritis.

Berkaitan dengan pembelajaran sejarah kontroversial, beberapa peristiwa sejarah yang dapat diklasifikasikan masih bersifat kontroversial antara lain Gerakan 30 September, peristiwa seputar Surat Perintah Sebelas Maret (Supersemar), Serangan Umum 1 Maret 1949, lahirnya Pancasila, lahirnya Orde
Baru, peristiwa seputar reformasi, sampai permasalahan integrasi TimorTimur. Akan tetapi, sejarah kontroversial yang paling banyak diperdebatkan di masyarakat adalah Gerakan 30 September, Supersemar, dan Serangan Umum 1 Maret 1949 (Adam, 2007:14).

Pelaksanaan pembelajaran sejarah kontroversial pada dasarnya telah diterapkan di sekolah. Akan tetapi, pelaksanaan pembelajaran sejarah kontroversial masih belum maksimal. Materi-materi yang diajarkan masih sebatas pada materi-materi yang tidak memberikan pengaruh dan bersinggungan langsung dengan masyarakat, seperti materi-materi dari sejarah yang terjadinya jauh dari masa sekarang. Sementara itu, materi-materi sejarah kontemporer yang bersifat sensitif dan politis belum diajarkan secara maksimal. Selain itu pada pelaksanaannya, intervensi penguasa masih sangat kuat dalam pendidikan sejarah. Dengan demikian, pelaksanaan pembelajaran sejarah kontroversial masih belum berjalan secara maksimal.

Dalam pelaksanaannya di dalam kelas, terjadi hal yang berlawanan dengan semangat reformasi pada pembelajaran sejarah kontroversial. Dalam pembelajaran sejarah kontroversial, terjadi ketidaksesuaian antara semangat reformasi yang menunjung tinggi semangat keterbukaan dan kebebasan mengemukakan pendapat dengan kenyataan pendidikan sejarah pada saat ini, yakni adanya seperangkat kebijakan pemerintah yang masih belum membuka peluang yang maksimal untuk pengembangan proses berpikir kritis. Hal ini nampak dikeluarkannya Surat Keputusan Jaksa Agung Nomor 019/A/ JA/03/2007 pada tanggal 5 Maret 2007 yang melarang buku-buku pelajaran sejarah yang tidak membahas pemberontakan (PKI) tahun 1948 dan 1965. Akibatnya, terjadi penarikan buku ajar be- 
sar-besaran disertai dengan pemusnaham buku tersebut secara massal. Adanya kenyataan yang seperti ini merupakan salah satu hal yang menghilangkan kaidah sejarah sebagai ilmu, sekaligus menjadikan sejarah sebagai alat indoktrinasi untuk menghasilkan pengikut yang penurut (Purwanto, 2006:270). Hal ini justru akan menimbulkan permasalahan baru dalam masyarakat dengan adanya "dosa sejarah" berupa vonis bersalah terhadap suatu kelompok masyarakat dan "dendam sejarah" berupa kebencian terhadap suatu kelompok masyarakat kepada kelompok lain akibat suatu peristiwa sejarah.

Dari pemikiran di atas, tujuan penelitian ini adalah (1) mengidentifikasi kendala-kendala yang ditemui guru dalam pembelajaran sejarah kontroversial di SMA Negeri Kota Semarang dan (2) menganalisis upaya-upaya yang dilakukan guru dalam pembelajarna sejarah kontroversial di SMA Negeri Kota Semarang. Dengan demikian secara teoretis, penelitian ini dapat dijadikan suatu kajian ilmiah tentang permasalahan yang ditemui dalam pembelajaran sejarah, khususnya sejarah kontroversial serta pemecahan masalahnya. Secara praktis, penelitian ini diharapkan mampu memberikan manfaat berupa gambaran tentang permasalahan pembelajaran sejarah dan identifikasi penyebab permasalahan, serta menawarkan alternatif pemecahannya. Bagi pemerintah dapat menjadi satu masukan tentang penentuan kebijakan pendidikan yang menekankan aspek berpikir kritis pada peserta didik.

\section{METODE PENELITIAN}

Penelitian ini menggunakan metode kualitatif sehingga akan menghasilkan data deskriptif berupa kata-kata tentang kendala-kendala guru dalam pengajaran sejarah dan upaya yang dilakukan untuk mengatasinya yang akan diamati. Penelitian ini mengambil lokasi penelitian di SMASMA Negeri di Kota Semarang. Penelitian dilaksanakan pada bulan Mei -Juli 2013. Teknik pengumpulan data dalam penelitian ini menggunakan beberapa metode yaitu (1) wawancara terhadap guru dan peserta didik, (2) pengamatan/observasi terhadap pelaksanaan pembelajaran, dan (3) dokumentasi terhadap perangkat perencanaan, pembelajaran, dan penilaian guru. Analisis yang dilakukan menggunakan model analisis model interaktif. Analisis data kualitatif terdiri atas alur kegiatan yang terjadi secara bersamaan, yaitu (1) reduksi data, (2) penyajian data, (3) penarikan kesimpulan. Analisis dilakukan secara berlanjut, berulang dan terus menerus untuk menjelaskan kendala guru dalam pembelajaran sejarah kontroversial di sekolah, khususnya pada materi tentang Gerakan 30 September dan Surat Perintah Sebelas Maret.

\section{HASIL DAN PEMBAHASAN}

\section{Relevansi Pedagogis Pembelajaran Se- jarah Kontroversial}

Pembelajaran sejarah kontroversial merupakan upaya untuk membahas dalam kelas isu-isu kontroversial dalam sejarah. Hal ini dilakukan dengan menghadirkan beragam perspektif tentang masa lalu secara berimbang di dalam kelas. Pembelajaran sejarah kontroversial didukung dengan adanya atmosfer yang saling mendukung untuk memahami secara mendalam permasalahan di masa lalu dan menguraikan maknanya untuk membangun kesadaran sejarah siswa. 
Pada dasarnya keberadaan pembelajaran sejarah kontroversial dapat dikembangkan dalam kurikulum di Indonesia. Berdasarkan penelitian Ahmad (2010) ternyata terdapat beberapa kompetensi dasar yang dapat dikaitkan dengan sejarah kontroversial, mulai dari konsep tentang sejarah sampai peristiwa sejarah kontemporer.

Ditinjau dari aspek relevansi pedagogis, pembelajaran sejarah kontroversial relevan terhadap setiap jenjang pendidikan, terutama jenjang menengah atas. Kuntowijoyo (2005) menjelaskan bahwa di jenjang SMA, siswa telah diajak untuk berpikir secara kritis tentang apa yang sebenarnya terjadi, dan ke mana arah kejadian tersebut. Bahkan menurut laporan dari The Historical Association (2008) pembelajaran sejarah kontroversial dapat dilakukan di tiap jenjang pendidikan, tentunya dengan pendekatan yang berbeda. Pada jenjang paling dasar, sejarah kontroversial dapat diajarkan dengan mengaitkan pada konsep persamaan/penerimaan dan perbedaan/pertentangan. Akan tetapi fokus dari tulisan ini lebih mengarah pada sejarah kontroversial bagi jenjang pendidikan menengah.

Pengajaran sejarah yang bersifat kontroversial dengan memberikan argumentasi yang kuat dan logis tentang pendapat-pendapat yang berbeda itu memiliki beberapa tujuan. Abu Su'ud (1993:20-21) menyatakan bahwa pengembangan pola isu kontroversial dalam kelas sejarah bertujuan untuk mencapai (1) peningkatan daya penalaran, (2) peningkatan daya kritik sosial, (3) peningkatan kepekaan sosial, (4) peningkatan toleransi dalam perbedaan pendapat, (5) peningkatan keberanian pengungkapan pendapat secara demokratis, serta (6) peningkatan kemampuan menjadi warga negara yang bertanggung jawab.

Misco (2007) serta Barton \&
McCully (2007) melihat bahwa isu kontroversial relevan dengan upaya pendidikan untuk demokratisasi. Hal ini karena isu-isu kontroversial, termasuk dalam sejarah, mampu membangkitkan sikap menghormati perbedaan pendapat tentang suatu permasalahan.

Davies (2007) dalam penelitiannya berjudul "Researching Controversial Issues in Citizenship Education" menyatakan bahwa terdapat relevansi antara isu kontroversial dan pendidikan bagi warga negara. Ia menegaskan bahwa pentingnya upaya menghadirkan isu kontroversial dalam pembelajaran dengan berdasarkan fakta secara menyeluruh dan berimbang. Hal senada diungkapkan oleh Fallahi \& Haney (2007) menjelaskan bahwa isu kontroversial dalam kelas berpotensi untuk mewujudkan warga negara yang baik. Melalui pembelajaran isu-isu kontroversial siswa terdorong untuk berpartisipasi secara aktif dalam mengungkapkan gagasannya dan memecahkan masalah. Namun demikian dinyatakan bahwa harus ada persiapan yang matang agar pembelajaran isu kontroversial dapat berjalan dengan baik.

Pembelajaran sejarah kontroversial bertujuan untuk menumbuhkan dan meningkatkan serangkaian kompetensi siswa. Secara mendasar tujuan utama dari pembelajaran sejarah kontroversial adalah meningkatkan pola pikir dan kesadaran kritis siswa (Phillips, 2008; James, 2009). Kesadaran kritis merupakan kemampuan memahami secara mendalam terhadap realitas dan mengambil peran untuk perubahan dan perbaikan keadaan masyarakat (social transformation) (Lestyana, 2004). Dengan demikian, kesadaran kritis memiliki makna sebagai sebuah kemampuan berpikir dan bertindak sekaligus.

Pembelajaran sejarah kontroversial juga bertujuan menunjang proses demokratisasi untuk mewujudkan war- 
ga negara yang baik. Konsep warga negara yang baik (effective citizenship) menurut Cogan \& Dericot (dikutip Berg, Graffe \& Holden, 2003) adalah adanya kemampuan bekerjasama dengan orang lain, membangun keadilan sosial, berpikir kritis dan sistematis, mampu melakukan penilaian terhadap permasalahan, menyelesaikan konflik tanpa kekerasan, peduli lingkungan, pengenalan dan penghargaan terhadap hak asasi, serta berpartisipasi dalam politik yang demokratis. Oleh karena itu, pembelajaran sejarah kontroversial akan menyiapkan siswa untuk peka terhadap perubahan yang cepat dan berbagai permasalahan di sekelilingnya.

\section{Kendala Guru dalam Pembelajaran Sejarah Kontroversial}

Pembelajaran yang mengulas peristiwa sejarah kontroversial yang bersifat kontemporer merupakan merupakan pembelajaran yang baru dalam pembelajaran Sejarah di Sekolah Menengah Atas. Oleh karena itu, memungkinkan kemunculan berbagai kendala dalam pelaksanaannya. Pada penelitian ini, kendala-kendala yang ditemui oleh guru sejarah dikelompokkan menjadi tiga, yakni (1) kendala pada saat perencanaan pembelajaran, (2) kendala pada aspek-aspek pembelajaran, dan (3) kendala pada faktor-faktor pendukung.

Pada aspek perencanaan, kendala yang ditemui oleh guru dalam pembelajaran untuk peristiwa sejarah yang bersifat kontroverisal meliputi (1) minimnya contoh-contoh rencana pembelajaran untuk materi kontroversi sejarah, (2) sumber-sumber masih terbatas, (3) akses untuk mendapatkan informasi yan sulit, (4) alokasi waktu yang terbatas dalam pembelajaran, (5) kebijakan pemerintah yang acap kali membingungkan guru dalam penyu- sunan perencanaan pembelajaran, (6) ada materi yang tidak memiliki alokasi waktu khusus dalam pembelajaran.

Kendala-kendala yang ditemui dalam aspek pembelajaran masih berpusat pada keterbatasan keterampilan guru dalam penerapan variasi pembelajaran, minimnya antusias peserta didik, materi yang memunculkan serangkaian kesulitan dalam pemahamannya, masalah dalam media pembelajaran, penerapan sistem evaluasi, serta keterbatasan fasilitas dan sumber. Kendala-kendala ini menyebabkan kegiatan pembelajaran tidak berjalan dengan optimal dan berlangsung secara tidak efektif. Pada faktor pendukung, kendala-kendala yang ditemui dalam aspek organisasi profesi dan keilmuan, perguruan tinggi, media massa, serta kebijakan pemerintah adalah ketidakoptimalan peran dari komponen-komponen pendukung serta belum optimalnya pemanfaatan media massa sebagai sumber belajar.

Dari penjelasan tentang berbagai hal tentang pembelajaran mulai dari perencanaan, pelaksanaan, dan peran komponen penunjang, ternyata ada beberapa faktor yang menyebabkan munculnya kendala dalam pembelajaran. Kendala-kendala yang ditemui dalam kelas sejarah secara umum dapat disebabkan oleh dua faktor, yakni (1) faktor internal dan (2) faktor eksternal. Faktor internal yang memunculkan permasalahan dalam pembelajaran sejarah kontroversial adalah faktor yang berasal dari dalam ilmu sejarah, yakni adanya perubahan dalam corak historiografi Indonesia posreformasi.

Faktor kedua adalah faktor eksternal yakni faktor-faktor luar yang berasal dari luar sejarah yang memengaruhi sejarah dan pendidikan sejarah. Antara faktor internal dan eksternal tersebut tidak berdiri sendiri (independent), tetapi menjadi satu rangkaian yang 
memunculkan hubungan kausalitas dan hubungan kebergantungan (interdependent), di mana faktor intern sangat mempengaruhi faktor ekstern.

Faktor internal yang menyebabkan permasalahan dalam pendidikan sejarah adalah terjadinya perubahan corak historiografi Indonesia yang memunculkan pendapat-pendapat yang beraneka ragam tentang satu peristiwa sejarah, seperti berkembangnya beberapa versi dari Gerakan 30 September tahun 1965. Akan tetapi, ketika di satu sisi terjadi perubahan corak historiografi Indonesia setelah jatuhnya Soeharto, hal ini tidak diimbangi dengan kesiapan untuk menerima perubahan tersebut. Hal ini karena pengaruh tradisi historiografi Indonesia dalam memahami, merekonstruksi, dan memaknai masa lalu masih sangat kuat, sehingga bagi masyarakat awam, hal ini justru memberikan kebingungan.

Berkaitan dengan perubahan corak historiografi Indonesia, adanya perbedaan versi dalam penulisan sejarah ini diakibatkan banyak hal, yakni subjektivitas, pemahaman masyarakat yang keliru, dan faktor kepentingan. Faktor subjektivitas bisa berasal dari pelaku sejarah atau sejarawan. Selain itu ada pula kemungkinan terbentuknya satu konstruk pemikiran yang kuat dalam masyarakat tentang satu pemahaman sejarah, walaupun belum tentu pemahaman yang selama ini diyakini adalah benar adanya. Hal ini karena masyarakat terpengaruh oleh wacana tertetu selama terus-menerus, seperti ketika pada pemerintahan Orde Baru masyarakat selalu diberikan wacana bahwa dalam G 30 S, PKI-lah yang menjadi dalang.

Teori-teori yang berkembang tentang peristiwa 1965 juga tidak diberitakan secara seimbang pada masa itu. Padahal permasalahan tentang pelaku G $30 \mathrm{~S}$ sampai sekarang masih simpang siur, dan ada beberapa teori lain selain PKI sebagai dalang yang muncul. Namun demikian, aspek yang paling berpengaruh dalam faktor internal dari penyebab munculnya permasalahan dalam pembelajaran sejarah adalah adanya kepentingan-kepentingan yang ada di dalam sejarah.

Ahmad (2010: 1) mengemukakan bawa pendidikan sejarah tidak pernah lepas dari unsur kepentingan politik. Di dalam praksisnya, minimal ada dua jenis kepentingan dalam pendidikan sejarah. Pertama, pendidikan sejarah dipandang sebagai alat untuk menumbuhkan nasionalisme dan kesadaran kolektif tentang identitas kebangsaan. Kedua, pendidikan sejarah dilihat sebagai alat legitimasi kekuasaan. Makna politis pertama dikategorikan sebagai kepentingan yang bersifat afirmatif. Sementara itu, makna kedua bersifat kompulsif dan manipulatif. Sifat kompulsif dan manipulatif itu disebabkan adanya pemanfaatan sejarah untuk kepentingan salah satu pihak dengan menonjolkan keunggulan-keunggulan penguasa dan mereduksi sejarah yang tidak sesuai dengan "sejarah resmi". Kepentingan politis yang ke dua inilah yang banyak mengakibatkan permasalahan dalam pembelajaran sejarah.

Kepentingan itu bisa datang dari pihak-pihak yang terlibat dalam satu peristiwa sejarah ataupun dari pihakpihak yang ingin memanfaatkan satu peristiwa sejarah untuk tujuan-tujuan tertentu. Kepentingan yang datang dari pihak pelaku sejarah ataupun keturunannya dikarenakan pelaku sejarah merasa dirugikan dengan adanya penulisan sejarah dari pihak tertentu.

Faktor eksternal yang menyebabkan munculnya permasalahan dalam pembelajaran sejarah yang kontroversial masih berada di seputar (1) lemahnya desain pembelajaran sejarah, (2) kebijakan tentang pendidikan sejarah yang 
Kendala-Kendala Guru ... - Tsabit Azinar Ahmad, dkk.

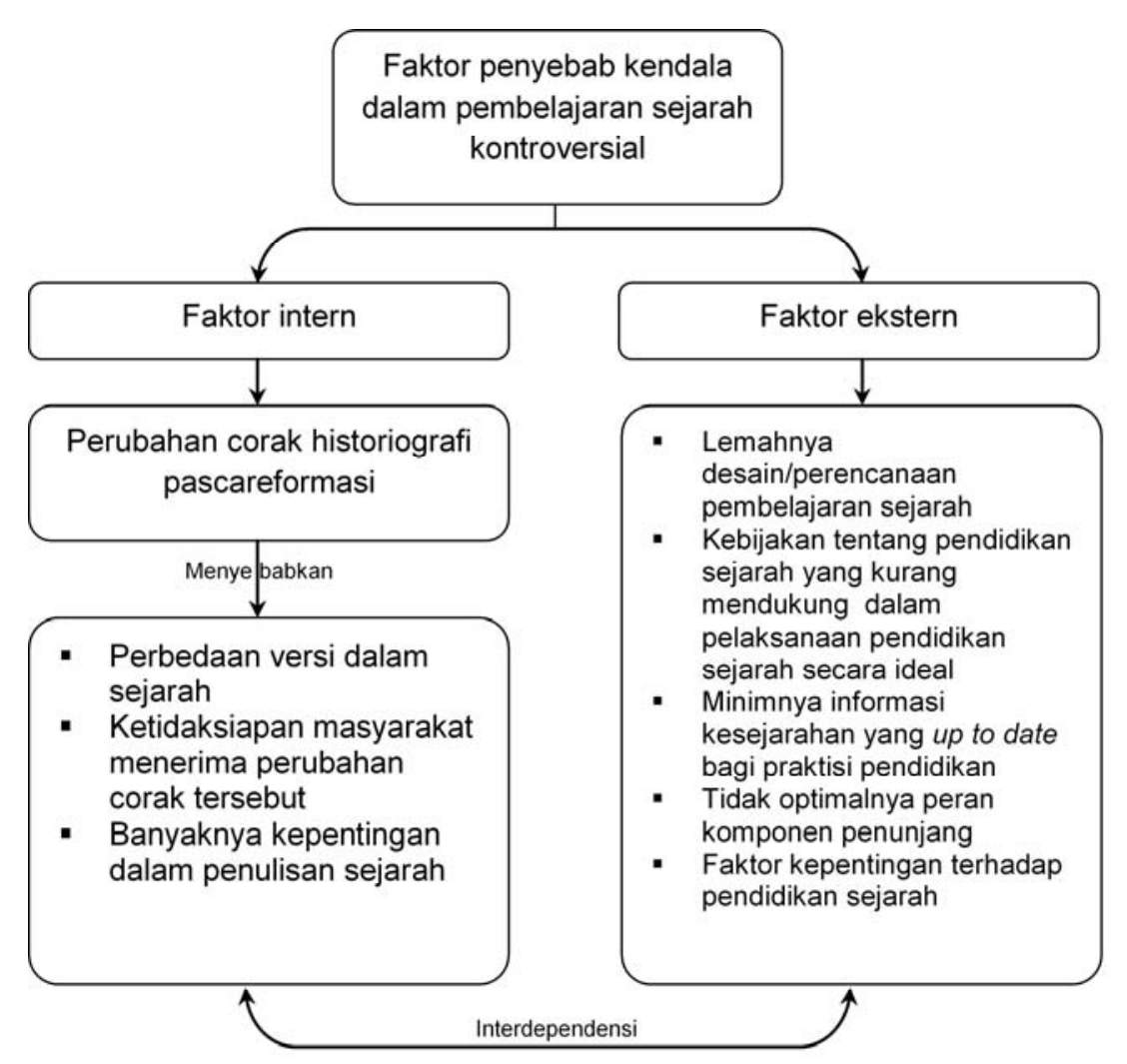

Gambar 1. Identifikasi Penyebab Permasalahan Pembelajaran Sejarah Kontroversial

kurang mendukung pelaksanaan pendidikan sejarah secara ideal, (3) minimnya informasi kesejarahan yang up to date bagi praktisi pendidikan, (4) tidak optimalnya peran komponen penunjang, serta (5) faktor kepentingan terhadap pendidikan sejarah.

Faktor kepentingan yang dimaksud adalah adanya campur tangan yang terlalu banyak dari pemerintah terhadap pendidikan sejarah, seperti ketika dikeluarkannya Surat Keputusan Jaksa Agung Nomor 019/A/JA/03/2007 pada tanggal 5 Maret 2007 yang melarang buku-buku pelajaran sejarah yang tidak membahas pemberontakan (PKI) tahun 1948 dan 1965. Walaupun pada dasarnya pendidikan sejarah merupakan alat dari pemerintah untuk menumbuhkan rasa cinta tanah air dan nasionalisme, akan tetapi ketika pemerintah terlalu banyak campur tangan, hal ini dapat menimbulkan satu anggapan bah- wa pendidikan sejarah justru menjadi satu alat legitimasi.

\section{Upaya Guru Mengatasi Kendala}

Adanya beberapa kendala dalam perencanaan dan pelaksanaan pembelajaran yang menuntut adanya upaya dalam mengatasi kendala-kendala tersebut. Upaya untuk mengatasi kendalakendala dalam aspek perencanaan, pada dasarnya sudah cukup baik, yakni guru mencoba untuk mengembangkan silabus yang telah disusun oleh pusat kurikulum dalam perencanaan, upaya pencarian sumber-sumber baru, pemanfaatan lingkungan sebagai sumber belajar, mencoba untuk tidak terpengaruh terhadap kebijakan pemerintah yang menimbulkan banyak kebingungan, serta melakukan tukar pikiran dengan rekan sesama guru se- 
jarah. Dalam hal pengembangan, guru mendapatkan kemudahan dan gambaran nyata tentang upaya penyusunan renana pelaksanaan setelah melihat contoh silabus yang disusun oleh pusat kurikulum. Kemudian dalam pencarian sumber-sumber baru guru merasa ini adalah suatu kebutuhan dalam pelaksanaan pembelajaran. Sumber-sumber baru ini didapatkan dari berbagai surat kabar, buku referensi, serta pemanfaatan sumber internet.

Salah satu upaya mengatasi kendala-kendala dalam pelaksanaan pembelajaran adalah guru berupaya untuk memanfaatkan lingkungan sekitar dalam pembelajaran. Pada aspek ini guru berupaya memanfaatkan secara maksimal fasilitas-fasilitas yang telah tersedia.

Pada pelaksanaan pembelajaran, guru telah menerapkan pembelajaran berbasis ICT (Information and Communitaion Technology). Dalam hal ini guru memanfaatkan internet sebagai sarana mendapatkan informasi tidak hanya bagi guru tetapi juga bagi peserta didik. Pemanfaatan internet menjadi salah satu hal yang memudahkan bagi guru dan peserta didik dalam penguasaan materi serta upaya mendapatkan informasi kesejarahan terbaru. Dari internet guru mendapatkan banyak informasi. Selain itu pemanfaatan internet bagi peserta didik selain sebagai sumber untuk mendapatkan informasi juga sebagai upaya meningkatkan motivasi belajar peserta didik terhadap pembelajaran sejarah.

Dalam hal kebijakan pemerintah, guru tidak terlalu merisaukan kebijakan -kebijakan pemerintah yang kadangkadang membingungkan oleh guru. Hal ini dikarenakan pada kurikulum tahun 2006 atau Kurikulum Tingkat Satuan Pendidikan (KTSP), guru memiliki wewenang yang luas dalam pelaksanaan pembelajaran, baik dalam penyusunan perencanaan ataupun da- lam pelaksanaan pembelajaran di kelas, baik perumusan tujuan, materi, metode pembelajaran, sistem evaluasi, sampai pemanfaatan fasilitas pendukung lainnya. Adanya kurikulum ini pada dasarnya memberikan keleluasaan bagi guru dalam mengatasi kendala-kendala yang ditemui.

Tukar pikiran dilakukan oleh guru dengan rekan sesama guru sejarah merupakan upaya untuk melakukan penyempurnaan dalam perencanaan pembelajaran dan pelakasnaan pembelajaran. Guru melakukan perbandingan dan diskusi tentang pelaksanaan pembelajaran. Upaya-upaya tersebut merupakan upaya-upaya yang dilakukan guru dalam pembelajaran sejarah kontroversial agar tujuan pembelajaran dapat tercapai.

\section{SIMPULAN}

Pembelajaran untuk peristiwa sejarah yang bersifat kontroversial telah diterapkan di SMA-SMA Negeri di Kota Semarang. Namun demikian, ada beberapa kendala yang ditemui dalam aspek perencanaan, pelaksanaan pembelajaran, sampai dengan komponen penunjuang lainnya yang menghambat pembelajaran. Kendala-kendala yang ditemui dalam kelas sejarah secara umum dapat disebabkan oleh dua faktor, yakni (1) faktor internal dan (2) faktor eksternal. Faktor internal yang memunculkan permasalahan dalam pembelajaran sejarah kontroversial adalah faktor yang berasal dari dalam ilmu sejarah, yakni adanya perubahan dalam corak historiografi Indonesia posreformasi. Faktor kedua adalah faktor eksternal yakni faktor-faktor luar yang berasal dari luar sejarah yang memengaruhi sejarah dan pendidikan sejarah. Untuk mengatasi permasalahan tersebut, guru melakukan pembenahan dalam aspek 
perencanaan, pengembangan strategi pembelajaran, pemanfaatan media dan fasilitas yang ada di sekitarnya. Selain itu, tukar pikiran dilakukan oleh guru dengan rekan sesama guru sejarah merupakan upaya untuk melakukan penyempurnaan dalam perencanaan pembelajaran dan pelakasnaan pembelajaran.

\section{UCAPAN TERIMA KASIH}

Penelitian ini terselenggara atas bantuan biaya penelitian desentralisasi pada skim hibah bersaing yang telah dilaksanakan selama dua tahun pada 2013-2014. Oleh karena itu, penulis mengucapkan terima kasih kepada LP2M Universitas Negeri Semarang dan Ditlitabmas Dikti, Kemendikbud.

\section{DAFTAR PUSTAKA}

Abu Su'ud. 1993. 'Bila Isu Kontroversial Masuk Kelas Sejarah (Sebuah Alternatif dalam Pengajaran Sejarah)'. Pidato Pengukuhan. Diucapkan pada penerimaan jabatan Guru Besar pada Fakultas Ilmu Pengetahuan Sosial IKIP Semarang pada 23 Januari 1993.

Adam, Asvi Warman. 2007. Seabad Kontroversi Sejarah. Yogyakarta: Penerbit Ombak.

Ahmad, Tsabit Azinar, dkk. 2008. 'Pendekatan Kritis dalam Pembelajaran Sejarah Kontroversial di Sekolah Menengah Atas untuk Mewujudkan Kesadaran Sejarah Peserta Didik'. Karya Tulis Ilmiah. Disusun dalam KKTM Bidang Pendidikan Tingkat Nasional pada 17 Juli 2008.

Ahmad, Tsabit Azinar. 2010. "Implementasi Critical Pedagogy dalam Pembelajaran Sejarah Kontroversial pada Sekolah Menengah Atas Negeri di Kota Semarang. Tesis. Surakarta: Program Studi Pendidikan Sejarah, Program Pascasarjana, Universitas Sebelas Maret.
Barton, Keith \& Mc Cully, Alan. 2007. "Teaching Controversial Issues, Where Controversial Issues Really Matter". Teaching History. No 127 Juni 2007.

Berg, Wolfgang; Graeffe, Leena \& Holden Cathie. 2003. Teaching Controversial Issues: an Europan Perspective. London: CiCe.

Cavet, Agnès. 2007. Teaching "controversial issues": a living, vital link between school and society?. Dalam http:// www.inrp.fr/vst/LettreVST/ english/27-may-2007_en.php? onglet=integrale. Diunduh 23 Februari 2010.

Davies, Ian. 2007. "Researching Controversial Issues in Citizenship Education". In Näsman, Elisabet; Navvaro, Alejandra; Cajani, Luigi; Davies, Ian \& Fülöp, Márta. Controversial Issues in Research. London: CiCe. Hlm. 5-7.

Global Citizenship Guides. 2006. Teaching Controversial Issues. London: Oxfam.

James, Jennifer H. 2009. “Reframing the Disclosure Debate: Confronting Issues of Transparency in Teaching Controversial Content". Social Studies Research and Practice. Vol. 4 (1). Hlm. 82-94.

Kochhar, S.K. 2008. Pembelajaran Sejarah. Penerjemah Purwanta dan Yofita Hardiwati. Jakarta: Grasindo.

Kuntowijoyo. 1995. Pengantar Ilmu Sejarah. Yogyakarta: Bentang Budaya.

Misco, Thomas. 2007. "Using Curriculum Deliberation to Address Controversial Issues: Developing Holocaust Education Curriculum for Latvian School". International Journal of Education Policy $\mathcal{E}$ Leadership. Vol. 2 (8). Hlm. 1-12.

Lestyana, Pepi. 2004. "Presence of Mind in the Process of Learning and Knowing: A Dialogue with Paulo Freire". Teacher Education Quarterly. Winter 2004. Hlm. 17-29.

Phillips, Ian. 2008. Reflective Teaching and Learning: A guide to professional issues for beginning secondary teachers. Los Angeles: Sage Publisher

Purwanto, Bambang. 2001. 'Reality and Myth in Contemporary Indonesian History'. Humaniora volume XIII, No. 2/2001. Hlm. 111-123. 
Paramita Vol. 24, No. 2 - Juli 2014

The Historical Association. 2008. “Teaching Association on Challenges and Emotive and Controversial History 319". A Report. The Historical Opportunities for Teaching Emotive and Controversial History 3-19. 